\title{
Whey protein phospholipid concentrate and delactosed permeate: Applications in caramel, ice cream, and cake
}

\author{
M. A. Levin, ${ }^{*}$ K. J. Burrington, $†$ and R. W. Hartel ${ }^{* 1}$ \\ *Department of Food Science, and \\ †Center for Dairy Research, University of Wisconsin-Madison, 1605 Linden Drive, Madison 53706-1565
}

\begin{abstract}
Whey protein phospholipid concentrate (WPPC) and delactosed permeate (DLP) are 2 coproducts of cheese whey processing that are currently underutilized. Past research has shown that WPPC and DLP can be used together as a functional dairy ingredient in foods such as ice cream, soup, and caramel. However, the scope of the research has been limited to a single WPPC supplier. The variability of the composition and functionality of WPPC was previously studied. The objective of this research was to expand on the previous study and examine the potential applications of WPPC and DLP blends in foods. In ice cream, WPPC was added as a natural emulsifier to replace synthetic emulsifiers. The WPPC decreased the amount of partially coalesced fat and increased the drip-through rate. In caramel, DLP and WPPC replaced sweetened condensed skim milk and lecithin. Cold flow increased significantly, and hardness and stickiness decreased. In cake, DLP and WPPC were added as a total replacement of eggs, with no change in yield, color, or texture. Overall, WPPC and DLP can be utilized as functional dairy ingredients at a lower cost in ice cream and cake but not in chewy caramel.
\end{abstract}

Key words: whey protein phospholipid concentrate, delactosed permeate, ice cream, caramel, cake

\section{INTRODUCTION}

Whey protein phospholipid concentrate (WPPC) and delactosed permeate (DLP) are products produced from the processing of cheese whey that are currently a utilization issue for the dairy industry. WPPC is a coproduct of whey protein isolate, produced from the microfiltration of whey protein concentrate, which separates the majority of the undenatured whey proteins from the fat, phospholipids, lactose, and denatured whey proteins. In 2015, the American Dairy Products

Received February 1, 2016.

Accepted May 15, 2016.

${ }^{1}$ Corresponding author: rwhartel@wisc.edu
Institute (2015) instituted a standard for WPPC composition: minimum of $50 \%$ protein (dry basis), minimum of $12 \%$ fat, maximum of $8 \%$ ash, and maximum of $6 \%$ moisture.

In previous research, WPPC composition, DLP composition, and the functionality, variability, and drying capabilities of both products were studied (Liang et al., 2009). Delactosed permeate is high in lactose, mineral, and organic acids and low in fat and protein, making it difficult to dry and incorporate into foods for human consumption. Whey protein phospholipid concentrate is high in fat and protein while being low in ash and lactose. Previous research showed that when WPPC and DLP were blended, they had key functional properties that could make them useful ingredients in food [R. Bund (University of Wisconsin-Madison) and R. Hartel, unpublished data]. Blends of WPPC and DLP have been studied in several food applications to replace other dairy products, emulsifiers, salt, and eggs in food applications such as ice cream, soups, and confections (Burrington, 2011; Bund and Hartel, 2013). However, the scope of the WPLC research was limited to one supplier (Burrington, 2011).

The aim of this research was to investigate different suppliers of WPPC and WPPC:DLP blends in food applications to replace other ingredients. Sweetened condensed skim milk was replaced in chewy caramel, and synthetic emulsifiers were replaced in ice cream. In cake, a full egg replacement was done. The results will provide valuable guidance for product developers to use these dairy coproducts in various food applications.

\section{MATERIALS AND METHODS}

\section{Materials}

Several WPPC powders were obtained: Perham $\mathrm{P}_{\mathrm{c}^{-}}$ PROTEIN from Bongards Creameries (Minneapolis, MN), Whey Phospholipid Protein Concentrate from Milk Specialties Global (Eden Prairie, MN), and Whey Protein Concentrate High Fat from Leprino Foods (Denver, CO). The composition of the WPPC powders can be found in Table 1, listed as A, B, and C. The 
Table 1. Proximate composition $( \pm \mathrm{SD})$ of whey protein phospholipid concentrates from each supplier $(\mathrm{n}=2$; M. Levin, R. Hartel, and K. Burrington, unpublished data)

\begin{tabular}{lccccc}
\hline & \multicolumn{5}{c}{ Component } \\
\cline { 2 - 6 } Supplier & Moisture (\%) & Fat (\%) & Protein (\%) & Lactose (\%) & Ash (\%) \\
\hline A & $4.53 \pm 0.04$ & $13.70 \pm 0.04$ & $69.97 \pm 0.02$ & $2.88 \pm 0.02$ & $2.07 \pm 0.01$ \\
B & $3.57 \pm 0.02$ & $15.63 \pm 0.25$ & $54.67 \pm 0.2$ & $3.48 \pm 0.29$ & $3.50 \pm 0.01$ \\
C & $4.33 \pm 0.01$ & $15.50 \pm 0.01$ & $50.26 \pm 0.19$ & $3.95 \pm 0.12$ & $3.61 \pm 0.03$ \\
\hline
\end{tabular}

only commercially dried delactosed permeate, Dairy Products Solid, was obtained from Leprino Foods.

\section{Caramel}

Ingredients. Sucrose was obtained from United Sugars (Edina, MN). Corn syrup (42-dextrose equivalent) was provided by Archer Daniels Midland (Decatur, IL). Sweetened condensed skim milk was provided by Galloway Company (Neenah, WI). Partially hydrogenated palm kernel oil (Silko 32-05) was supplied by Aarhus Karlshamn (Port Newark, NJ). The water used was deionized in Babcock Hall (University of Wisconsin, Madison). Salt was supplied by Morton Salt Inc. (Chicago, IL). Soy lecithin (Clearate B-60) was supplied by W. A. Cleary Product Inc. (Somerset, NJ). Lactose was obtained from Foremost Farms (Baraboo, WI). All ingredients used were from the same lots.

Formulation. Caramel formulations were based on representative industry formulas for cut and wrap caramel (Jackson, 2000; Hofberger, 2009). All caramels were formulated for a final moisture content of $10.5 \%$, fat content of $12.5 \%$, protein content of $2.5 \%$, reducing sugar content of $18.1 \%$, and a corn syrup solids to su- crose ratio of 50:50. The initial premix had a moisture content of $30 \%$ to ensure all sucrose and lactose were dissolved. The WPPC and DLP blends were added to fully replace the protein provided by the sweetened condensed milk. Additionally, the lecithin was removed in the negative control and test formulations to investigate the emulsifying capabilities of WPPC. Whey protein phospholipid concentrate samples A, B, and C were added both alone and with a 30:70 DLP:WPPC blend. Lactose was added to maintain a reducing sugar content of $18.1 \%$ to ensure that any difference in Maillard browning was due to the protein source and not the reducing sugar content. The formulas of the premixes are shown in Table 2.

Cooking Procedure. Each batch of caramel was prepared in 1-kg batches. The WPPC and DLP:WPPC blends were prehydrated for $1 \mathrm{~h}$ with $150 \mathrm{~mL}$ of deionized water to ensure full hydration of the proteins. All ingredients were weighed into a 3.8 -L (4-quart) induction saucepan (Carlisle, Oklahoma City, OK) and cooked on a SR-951T, 120-V, 1400-W induction cooker (Sunpentown, City of Industry, CA). A scraped surface stirring apparatus made from heat-resistant spatulas (Newell Rubbermaid Inc., Atlanta, GA) was used to

Table 2. Caramel formulation

\begin{tabular}{lrrrrrrrc}
\hline & \multicolumn{7}{c}{ Formula $^{2}$} \\
\cline { 2 - 8 } Ingredient $^{1}$ & \multicolumn{1}{c}{$\mathrm{C}$} & \multicolumn{1}{c}{$\mathrm{C}$} & $\mathrm{A}$ & $30: 70 \mathrm{~A}$ & \multicolumn{1}{c}{$\mathrm{B}$} & $30: 70 \mathrm{~B}$ & $\mathrm{C}$ & $30: 70 \mathrm{C}$ \\
\hline Water & 23.67 & 23.67 & 28.69 & 28.69 & 29.18 & 28.87 & 28.83 & 28.89 \\
Sucrose & 17.49 & 17.40 & 25.18 & 24.97 & 24.75 & 24.52 & 24.75 & 24.37 \\
HFCS & 31.31 & 31.42 & 31.49 & 31.22 & 30.92 & 30.66 & 30.92 & 30.4 \\
SCSM & 17.98 & 17.99 & 0.00 & 0.00 & 0.00 & 0.00 & 0.00 & 0.00 \\
PKO & 8.88 & 8.96 & 8.69 & 8.67 & 8.45 & 8.50 & 8.45 & 8.45 \\
Salt & 0.50 & 0.50 & 0.50 & 0.50 & 0.50 & 0.50 & 0.50 & 0.50 \\
Lecithin & 0.15 & 0.00 & 0.00 & 0.00 & 0.00 & 0.00 & 0.00 & 0.00 \\
Lactose & 0.00 & 0.00 & 2.88 & 2.29 & 2.92 & 2.23 & 2.96 & 2.19 \\
WPPC A & 0.00 & 0.00 & 2.57 & 2.75 & 0.00 & 0.00 & 0.00 & 0.00 \\
WPPC B & 0.00 & 0.00 & 0.00 & 0.00 & 3.28 & 3.30 & 0.00 & 0.00 \\
WPPC C & 0.00 & 0.00 & 0.00 & 0.00 & 0.00 & 0.00 & 3.59 & 3.59 \\
DLP & 0.00 & 0.00 & 0.00 & 0.92 & 0.00 & 1.42 & 0.00 & 1.54 \\
\hline
\end{tabular}

${ }^{1} \mathrm{HFCS}=42$-dextrose equivalent high fructose corn syrup; $\mathrm{SCSM}=$ sweetened condensed skim milk; $\mathrm{PKO}=$ palm kernel oil; WPPC = whey protein phospholipid concentrate; DLP = delactosed permeate.

${ }^{2}$ Formulas: $+\mathrm{C}=$ positive control; $-\mathrm{C}=$ negative control; $\mathrm{A}=$ WPPC $\mathrm{A} ; 30: 70 \mathrm{~A}=30 \% \mathrm{DLP}$ and $70 \%$ WPPC A; B = WPPC B; 30:70 B = 30\% DLP and 70\% WPPC B; C = WPPC C; 30:70 C = 30\% DLP and $70 \%$ WPPC C. 
prevent scorching. The stirring apparatus was attached to a mixer, Stir-Pak laboratory mixer (model 50002-10, Cole Palmer, Vernon Hills, IL) and stirred at setting 5 (90 rpm). A Traceble (Control Company, Rochester, NY) long-stem thermometer was submerged $1 \mathrm{~cm}$ into the caramel, without touching the base of the saucepan, to ensure accurate temperature readings. The caramel premix was heated until it reached $60^{\circ} \mathrm{C}$ and homogenized for 1 min using a 2-speed Hand Blender (KitchenAid, St. Joseph, MI) to ensure that the lecithin and fat were properly dispersed. The premix was then kept at $60^{\circ} \mathrm{C}$ for $10 \mathrm{~min}$ to fully dissolve the sugars and melt the fat (melting point: $35^{\circ} \mathrm{C}$ ) and again homogenized. The mix was cooked to $115.6^{\circ} \mathrm{C}$, using continuous stirring to obtain a final moisture content of $10.5 \%$. After the caramel had reached the final cook temperature, it was removed from the saucepan to prevent additional heating and moisture loss. The caramel was hot filled into molds to prevent alteration of the microstructure during cutting and forming (McMaster et al., 1987). Four types of molds were used for the caramel analysis. All molds were oiled before being filled with caramel to prevent sticking and disruption of the microstructure.

Moisture Content. Moisture content of caramel samples was tested to ensure that the proper cook temperature was reached. All caramels were cooked to $10.5 \%$ moisture $\pm 0.1 \%$ to ensure that the solutes had been equally concentrated, eliminating moisture content as a variable (Miller, 2012). Caramel samples of $0.2 \pm 0.05 \mathrm{~g}$ were weighed and dissolved in the testing chamber in a 4:3 mixture of formamide and methanol for $10 \mathrm{~min}$ at $50^{\circ} \mathrm{C}$. The Karl Fischer titer was automatically added until a potentiometric endpoint was determined, and the moisture content was based on the weight of the samples and the volume of titer consumed (Bruttel and Schlink, 2003). All caramel formulations were made in duplicate and tested in triplicate.

Colorimetry. Color of the caramel samples was measured using a Minolta Chroma Meter CR-300 (Minolta Corporation, Ramsey, NJ) using a CIELAB color scale system, which measures $\mathrm{L}^{*} \mathrm{a}^{*} \mathrm{~b}^{*}$; $\mathrm{L}^{*}$ measures the lightness versus darkness scale; $\mathrm{a}^{*}$ measures red-green color; and $\mathrm{b}^{*}$ measures yellow-blue color. All measurements were done in average daylight. The caramel samples were tested for color before cutting to ensure that the surface color was not modified. All caramel formulations were made in duplicate and tested in triplicate.

Water Activity. Water activity was measured using an Aqualab 3TE water activity meter (Decagon, Pullman, WA) to find the equilibrium relative humidity of the caramel samples. All caramel samples were taken from the center of the 118-mL (4-ounce) container, placed in the sample cups at a depth of $5 \mathrm{~cm}$, and immediately placed into the machine for a reading to prevent moisture loss.

Cold Flow. The cold flow samples were prepared by pouring the hot caramel into 2-piece Teflon molds with cylindrical holes of $19-\mathrm{mm}$ diameter by $19-\mathrm{mm}$ height. After $24 \mathrm{~h}$, the samples were removed from the molds without disrupting the crystal structure, and the diameter was measured using a digital caliper. The cylinders of caramel were then positioned on $0.05-\mathrm{mm}$ acetate sheets (3M Company, Maplewood, MN), placed in a humidity-controlled chamber kept at $55 \%$ relative humidity [using $\mathrm{Mg}\left(\mathrm{NO}_{3}\right)_{2}$ saturated salt solution], kept in a temperature-controlled room at $20 \pm 0.5^{\circ} \mathrm{C}$, and held for $24 \mathrm{~h}$. The diameter of the cylinders was again measured. Cold flow was determined based on the following equation:

$$
\text { Cold flow }(\%)=\frac{D_{24}-D_{0}}{D_{0}} \times 100,
$$

where $D_{0}$ is the average of the 3 diameters at time zero and $D_{24}$ is the average of the 3 diameters at time $24 \mathrm{~h}$. Three cylinders were analyzed for each caramel.

Texture Analysis. The compression samples were prepared by pouring excess hot caramel into $28-\mathrm{mm}$ diameter by $10-\mathrm{mm}$ height aluminum pans (VWR North American, West Chester, PA). A TA.XT2 texture analyzer (Texture Technologies, Hamilton, MA) with Exponent software (Stable Micro System, Surrey, UK) was used for all texture tests. Immediately before testing, the excess caramel was cut from the top of the aluminum pan to expose a fresh surface. A TA-8 stainless steel, spherical probe (Texture Technologies) was used for the hardness and stickiness tests. The test started once the probe experienced a trigger force of 5 g. The probe then descended at a rate of $5 \mathrm{~mm} / \mathrm{s}$ for a penetration depth of $8 \mathrm{~mm}$, paused for $1 \mathrm{~s}$, and raised to the initial height at a rate of $5 \mathrm{~mm} / \mathrm{s}$. The peak positive force was recorded as the hardness, and the peak negative force was recorded as the stickiness. Five readings were taken per caramel.

\section{Ice Cream}

Ingredients. Nonfat dry milk was obtained from Dairy America (Fresno, CA). Cream was obtained from Babcock Hall Dairy Plant (Madison, WI). Sucrose was obtained from United Sugars (Edina, MN). Gum stabilizer, Germantown Premium Ice Cream Stabilizer, and mono- and diglycerides were obtained from Dupont (New Century, KS). Polysorbate 80 was obtained from Agropur (La Crosse, WI). Lactose was obtained from Foremost Farms (Baraboo, WI). Ice cream formulas 
were randomized for production and were made in duplicate and tested in triplicated unless otherwise stated.

Formulation. The control ice cream formulation was based on the white mix made by the Babcock Hall Dairy Plant. Whey protein phospholipid concentrate was added at 1 and $2 \%$ to align with the standard identity for ice cream: "Any whey and modified whey products used contribute, singly or in combination, not more than 25 percent by weight of the total nonfat milk solids content of the finished food" (US FDA, 2006). All ice creams were formulated to have $17 \%$ sugar, $12.5 \%$ fat, and a freezing point of $-2.52^{\circ} \mathrm{C}$. Lactose was added to ensure the correct freezing point was obtained. The formulation can be found in Table 3. The WPPC was added to replace the emulsifiers in the positive control. The negative control had no emulsifier added and no WPPC. The WPPC was added at either 1 or $2 \%$ of the total formulation to replace the emulsifiers.

Processing. The ice cream mix was made in 19-kg batches. All of the ingredients were mixed while being heated in a Stephan mixer (Stephan Food Processing Machinery, Hamelin, Germany) to $84^{\circ} \mathrm{C}$ for $20 \mathrm{~s}$. The mixture was then homogenized in a 2-stage homogenizer (APV Fluid Handling, type 125"E; Lake Mills, WI) at 17.2 and $3.4 \mathrm{MPa}$. The mix was then cooled to $15^{\circ} \mathrm{C}$ in the Stephan mixer before being placed in a $4^{\circ} \mathrm{C}$ refrigerator for $24 \mathrm{~h}$ to age.

All freezing was done in a Stoelting VB25 ice cream freezer (Telme, Kiel, WI). Six liters was frozen at a time. The freezer was set to freeze until the product reached $-8^{\circ} \mathrm{C}$. The total time to freeze was between 11.5 and 12.5 min. After freezing was complete, the ice cream was scooped into pints and placed in a freezer at $-30^{\circ} \mathrm{C}$ for hardening before further analysis.
Viscosity. The viscosity of the aged mixes was measured on a Discovery HR-2 hybrid rheometer (TA Instruments, New Castle, DE) using cup-and-bob geometry. The mix was measured at $4^{\circ} \mathrm{C}$ using a shear sweep from 100 to 1/s. The data were fit to the Herschel-Bulkley model:

$$
\sigma=\sigma_{0}+K \dot{\gamma}^{n}
$$

where $\sigma$ is the shear stress $(\mathrm{Pa}), \sigma_{0}$ is the yield stress $(\mathrm{Pa}), \dot{\gamma}$ is shear rate $\left(\mathrm{s}^{-1}\right), K$ is the consistency coefficient $\left(\mathrm{Pa} \cdot \mathrm{s}^{n}\right)$, and $n$ is the flow behavior index (Nielsen, 2010).

Overrun. Overrun is a test to determine the percentage of air incorporated into the ice cream during the freezing process. It was calculated based on the weight (wt) of a specific volume of ice cream mix and frozen ice cream. A standard ice cream scoop was used for these measurements. Overrun was calculated using the following equation:

$$
\text { Overrun }(\%)=\frac{\text { Mix wt }(\mathrm{g})-\text { Ice cream wt }(\mathrm{g})}{\text { Ice cream wt }(\mathrm{g})} \times 100 \text {. }
$$

Ice Crystal and Air Cell Size. All ice crystal and air cell analysis was performed in a refrigerated glove box (described in Donhowe et al., 1991; Chang and Hartel, 2002). The ice cream samples were tempered to $-15^{\circ} \mathrm{C}$ for $30 \mathrm{~min}$. While in the glove box, a small sample from the center of the pint was placed on a glass slide with 1 drop of a 50:50 mixture of pentanol:kerosene to disperse the crystals. A coverslip was then placed on

\begin{tabular}{|c|c|c|c|c|c|c|c|c|}
\hline \multirow[b]{2}{*}{ Ingredient $^{1}$} & \multicolumn{8}{|c|}{ Formula $^{2}$} \\
\hline & $+\mathrm{C}$ & $-\mathrm{C}$ & $\mathrm{A} 1$ & $\mathrm{~A} 2$ & B1 & B2 & $\mathrm{C} 1$ & $\mathrm{C} 2$ \\
\hline Water & 32.00 & 32.00 & 32.00 & 32.00 & 32.00 & 32.00 & 32.00 & 32.00 \\
\hline Cream & 43.00 & 43.35 & 42.95 & 42.60 & 42.80 & 42.20 & 43.10 & 42.60 \\
\hline Sucrose & 16.30 & 16.30 & 16.30 & 16.30 & 16.30 & 16.30 & 16.30 & 16.30 \\
\hline M\&DG & 0.12 & 0.00 & 0.00 & 0.00 & 0.00 & 0.00 & 0.00 & 0.00 \\
\hline PS80 & 0.03 & 0.00 & 0.00 & 0.00 & 0.00 & 0.00 & 0.00 & 0.00 \\
\hline Stabilizer & 0.28 & 0.28 & 0.28 & 0.28 & 0.28 & 0.28 & 0.28 & 0.28 \\
\hline NFDM & 8.35 & 8.35 & 7.35 & 6.35 & 7.35 & 6.35 & 7.35 & 6.35 \\
\hline Lactose & 0.00 & 0.00 & 0.25 & 0.50 & 0.20 & 0.35 & 0.24 & 0.40 \\
\hline WPPC A & 0.00 & 0.00 & 1.00 & 2.00 & 0.00 & 0.00 & 0.00 & 0.00 \\
\hline WPPC B & 0.00 & 0.00 & 0.00 & 0.00 & 1.00 & 2.00 & 0.00 & 0.00 \\
\hline WPPC C & 0.00 & 0.00 & 0.00 & 0.00 & 0.00 & 0.00 & 1.00 & 2.00 \\
\hline
\end{tabular}

Table 3. Ice cream formulation 
top, and tweezers were used to spread the crystals into one plane. The ice crystals were viewed at $40 \times$ using a light microscope (Nikon Inc., Garden City, NY) and a Kohu solid-state analog camera. The images were taken using Optimus Software (Optimus Corporation, Bothell, WA). Fifteen images were taken per pint.

The ice crystal images were edited using Microsoft Paint version 5.1 (Microsoft Corporation, Belleview, WA). For each ice cream batch, 300 to 400 ice crystals were traced in triplicate, by adding a solid black line around the edge of each crystal. The traced images were analyzed using Image Pro Plus version 7.0.1 (Media Cybernetics, Rockville, MD) using the "count and size" feature.

To analyze the air cells, 2 glass coverslips were glued to a glass slide $2 \mathrm{~cm}$ apart to create a well. The tempered ice cream in the glove box was thinly sliced. The slice was placed in the well on the glass slide, covered with a glass coverslip, and pressed with a tweezer to ensure it was flush with the other coverslips. The temperature in the glove box was raised to $-6^{\circ} \mathrm{C}$ for 20 min to melt some of the ice crystals and allow the air cells to rise to the top of the sample. Each sample was imaged to capture 15 pictures.

The imaged air cells were analyzed in Image Pro Plus. Circles were drawn around 300 to 400 air cells and analyzed using the count and size feature. The size of the ice crystals and air cells were reported as the diameter of an equivalent circle measured using each method.

Fat Globule Size Distribution. The fat globule size distribution was determined for the ice cream mix after homogenization and for the melted ice cream. The size distribution was determined using a Malvern Mastersizer 2000 (Malvern Instruments Ltd., Malvern, UK), which uses laser light scattering to quantify the particle size. Deionized water with a refractive index of 1.33 was used as a dispersant for the mix and ice cream. The dispersed phase, milk fat, was measured with a refractive index of 1.46. The obscuration values were set at 14 to $16 \%$ (Goff and Hartel, 2013).

This method was used to determine the degree of partially coalesced fat globules in the ice cream. The size distribution of the mix and ice cream form specific peaks, the smallest of which is the protein $(\sim 0.4 \mu \mathrm{m})$, the middle is the single fat globules in the emulsion $(\sim 1 \mu \mathrm{m})$, and the largest is the partially coalesced fat globules $(\sim 10-100 \mu \mathrm{m})$. The homogenized mix will only have the first 2 peaks because the partially coalesced fat is formed by the shear during the freezing process. The percentage of partially coalesced fat is determined by the ratio of the fat globule clusters (third peak in ice cream) to the original fat globules in the mix (second peak in mix):

$$
\begin{aligned}
& \text { Partially coalesced fat }(\%)= \\
& \frac{\text { Area of third peak in ice cream }}{\text { Area of second peak in mix }} \times 100 \text {. }
\end{aligned}
$$

Microscope images were taken to confirm the Mastersizer data.

Melt Rate. The melt rate of the ice cream was determined by first allowing the ice cream to temper to $-15^{\circ} \mathrm{C}$ for $1 \mathrm{~h}$. An 80 -g cylindrical sample was cut from the pint and placed on a wire screen (3 openings $/ \mathrm{cm}$ ). The sample and screen were placed on a ring stand suspending them over a beaker and scale in a temperature-controlled room at $20^{\circ} \mathrm{C} \pm 0.5$. As the ice cream was allowed to melt, the weight of the melted ice cream drip through was measured every $5 \mathrm{~min}$. The test was allowed to progress for $2 \mathrm{~h}$. The rate of melting was calculated by plotting the weight of the drip through versus time and finding the slope of the linear region (Muse and Hartel, 2004).

\section{Cake}

Ingredients. All ingredients were purchased from Metcalfe Sentry Grocery Store (Madison, WI). Granulated sucrose was obtained from Domino Sugar (Chicago, IL). Softasilk flour was obtained from Pillsbury Baking (Minneapolis, MN). Whole eggs were obtained from Phil's Fresh Eggs (Foreston, IL). Crisco shortening was obtained from J.M. Smucker Company (Orville, OH). Double-acting baking powder was obtained from Clabber Girl Corporation (Terre Haute, IN). Salt was obtained from Morton Salt Inc., and Bourbon Vanilla Extract was obtained from Lochhead Mfg. Company (Paso Robles, CA). Water was deionized in Babcock Hall. All ingredients used were from the same lot.

Cake formulas were randomized for production and were made in duplicate and tested in triplicated unless otherwise stated.

Formulation. The control cake formulation was based on the standard white cake formulation used in the Wisconsin Center for Dairy Research. In the test formulations, eggs were replaced by WPPC and the 30:70 DLP:WPPC blend. The replacement was done based on the weight of protein. Additional water was added to the test cakes to replace the water found in eggs. Cake formulations can be found in Table 4 .

Processing. Cakes were made using the Wisconsin Center for Dairy Research cake method. All dry ingredients were placed in the bowl of a KitchenAid Professional 600-Lift Stand Mixer with a flat beater (Whirlpool, Benton Charter Township, MI) and stirred on speed 2 for $60 \mathrm{~s}$. The shortening was added and 
mixed on speed 2 for $60 \mathrm{~s}$ and speed 4 for $60 \mathrm{~s}$. Half of the wet ingredients were added and mixed on speed 2 for $60 \mathrm{~s}$ and speed 6 for $60 \mathrm{~s}$. One-fourth of the wet ingredients were added and mixed on speed 2 for $60 \mathrm{~s}$ and speed 6 for $60 \mathrm{~s}$. The remaining one-fourth of the wet ingredients were added and mixed on speed 2 for $30 \mathrm{~s}$ and speed 6 for seconds. The bowl and beater were scraped with a rubber spatula between each ingredient addition to remove buildup of cake batter and ensure proper mixing.

Next, $675 \mathrm{~g}$ of batter was poured into a $30.5-\mathrm{cm}$ cake pan (Calphalon, Newell Rubbermaid Inc., Atlanta, GA) lined with parchment paper (Chefland, Airmont, NY), greased with shortening, and floured with cake flour to prevent sticking. Cakes were baked at $180^{\circ} \mathrm{C}$ in a gas oven (model XL44, General Electric, Fairfield, CT) for $37 \mathrm{~min}$, before being removed from the oven and allowed to cool to room temperature on a wire rack to enhance airflow. Once cooled, the cakes were stored in 7.6-L plastic bags (Dow Chemical Company, Midland, MI) for $24 \mathrm{~h}$ to equilibrate before testing.

Yield. The yield of the cakes was measured by taking the weight (wt) of the cake before and after baking. The yield was calculated by

$$
\text { Yield }(\%)=\frac{\text { Cake wt }(\mathrm{g})-\text { Pan wt }(\mathrm{g})}{\text { Batter wt }(\mathrm{g})-\text { Pan wt }(\mathrm{g})} \times 100 \text {. }
$$

Volume. The volume was measured by rapeseed displacement, approved method 10-15 (AACC International, 2009). The cakes were wrapped in plastic wrap (Saran, S. C. Johnson Co., Racine, WI) to prevent seeds sticking to the cake. The cake was then placed in a measuring apparatus into which a known volume of rapeseeds was poured around and over the cake. The volume of the cake was calculated by

Cake volume $=$ Volume $_{\text {cake+rapeseeds }}-$ Volume $_{\text {rapeseeds }}$.

Height. Each cake was cut in half using a sharp knife. The height of the cake was measured at the center and at each side. These measurements were used to analyze the cake contour, which was defined as the difference between the height of the sides and the height of the middle.

Colorimetry. Color of the cake crust was measured using a Minolta Chroma Meter CR-300 using a CIELAB color scale system, which measures $\mathrm{L}^{*} \mathrm{a}^{*} \mathrm{~b}^{*}$. The cake samples were tested for color before cutting to ensure that no alteration was done to the surface color.

Water Activity. Water activity was measured using an Aqualab 3TE water activity meter (Decagon, Pullman, WA) to find the equilibrium relative humidity of the cake samples. A 10-cm slice of cake was cut into small pieces and mixed to ensure an even distribution of cake from the edges and the center. The samples were placed in the sample cups at a depth of $5 \mathrm{~mm}$, and immediately placed into the machine for a reading to prevent moisture loss.

Texture Profile Analysis. The cake samples were tested on a TA.XT2 texture analyzer with Exponent software and a TA-11 2.5-cm diameter acrylic probe (Texture Technologies). The probe was lowered to a depth of $5 \mathrm{~mm}$ at a test speed of $2 \mathrm{~mm} / \mathrm{s}$ and then raised $5 \mathrm{~mm}$ at a test speed of $2 \mathrm{~mm} / \mathrm{s}$. This process was repeated twice to mimic 2 bites. The trigger force of $3 \mathrm{~N}$ was used to start the test.

Table 4. Cake formulations

\begin{tabular}{lrrrrrrc}
\hline & \multicolumn{7}{c}{ Formula $^{2}$} \\
\cline { 2 - 8 } Ingredient $^{1}$ & Control & $\mathrm{A}$ & $30: 70 \mathrm{~A}$ & $\mathrm{~B}$ & $30: 70 \mathrm{~B}$ & $\mathrm{C}$ & $30: 70 \mathrm{C}$ \\
\hline Water & 24.39 & 33.84 & 33.53 & 33.73 & 33.36 & 33.80 & 33.48 \\
Sugar & 27.45 & 27.73 & 27.48 & 27.64 & 27.34 & 27.70 & 27.43 \\
Flour & 23.36 & 23.60 & 23.38 & 23.52 & 23.26 & 23.57 & 23.35 \\
Shortening & 10.10 & 10.20 & 10.11 & 10.17 & 10.06 & 10.19 & 10.10 \\
DABP & 1.40 & 1.41 & 1.40 & 1.41 & 1.39 & 1.41 & 1.40 \\
Salt & 0.60 & 0.61 & 0.60 & 0.60 & 0.60 & 0.61 & 0.60 \\
Vanilla & 0.50 & 0.51 & 0.50 & 0.51 & 0.50 & 0.51 & 0.50 \\
Eggs & 12.20 & 0.00 & 0.00 & 0.00 & 0.00 & 0.00 & 0.00 \\
WPPC A & 0.00 & 2.10 & 2.10 & 0.00 & 0.00 & 0.00 & 0.00 \\
WPPC B & 0.00 & 0.00 & 0.00 & 2.42 & 2.42 & 0.00 & 0.00 \\
WPPC C & 0.00 & 0.00 & 0.00 & 0.00 & 0.00 & 2.21 & 2.21 \\
DLP & 0.00 & 0.00 & 0.90 & 0.00 & 1.07 & 0.00 & 0.93 \\
\hline
\end{tabular}

${ }^{1} \mathrm{DABP}=$ double-acting baking powder; $\mathrm{WPPC}=$ whey protein phospholipid concentrate; $\mathrm{DLP}=$ delactosed permeate.

${ }^{2}$ Formulas: $\mathrm{A}=\mathrm{WPPC} \mathrm{A} ; 30: 70 \mathrm{~A}=30 \% \mathrm{DLP}$ and $70 \% \mathrm{WPPC} \mathrm{A} ; \mathrm{B}=\mathrm{WPPC} \mathrm{B} ; 30: 70 \mathrm{~B}=30 \% \mathrm{DLP}$ and $70 \%$ WPPC B; C = WPPC C; 30:70 C = 30\% DLP and 70\% WPPC C. 
The cakes were tested in 5 different places to ensure the variability of the cakes was captured. Hardness, cohesiveness, springiness, and chewiness were recorded.

\section{Statistical Analysis}

All statistical analysis was performed in JMP Pro 11 (SAS Institute Inc., Cary, NC). Data were analyzed using one-way ANOVA and Tukey tests with $\alpha<0.05$.

\section{RESULTS AND DISCUSSION}

\section{Caramel}

This experiment investigated total replacement of lecithin and SCSM with WPPC and DLP:WPPC blends. All caramels were cooked to $10.5 \pm 0.1 \%$ moisture content. A one-way ANOVA showed no significant differences in moisture content of the caramels $(P=$ $0.5301)$.

Colorimetry. The color in caramel is due to Maillard browning, which produces dark pigments when reducing sugars react with free amino groups. The $\mathrm{L}^{*}$ values for the caramels are reported in Table 5, with a higher $\mathrm{L}^{*}$ value indicating a lighter product. A one-way ANOVA indicated that significant differences existed among the means $\left(F_{47.7}=64.5143, P<0.0001\right)$. A post hoc Tukey's honestly significant difference (HSD) showed that the control formulas were significantly darker than the test formulas $(P<0.0001)$. In contrast, previous research found that caramels made with whey powders resulted in a darker final product (Foegeding and Steiner, 2002). However, that study did not have a standardized amount of reducing sugars in the caramels, and the high amount of lactose in the whey powders most likely resulted in an increase in Maillard browning.

The formulations with DLP had significantly higher $\mathrm{L}^{*}$ values showing that they were lighter than both the
WPPC caramels and the control formulations. Delactosed permeate decreased the $\mathrm{pH}$, which decreased the rate at which Maillard browning occurs. The lactose and protein content were kept constant by adjusting the amount of WPPC and lactose in the formulation.

Water Activity. Water activity is a measure of the water available to participate in reactions and is affected by the amount of dissolved solids; therefore, on a weight basis, smaller molecules have a greater effect on water activity. Water activity is most affected in caramels by the corn syrup to sucrose ratio and moisture content (Miller, 2012).

The caramel samples with WPPC had similar water activities, with an average of $0.492 \pm 0.011$, because of the similar formulations. However, a one-way ANOVA indicated statistical differences among the means $\left(F_{47,7}\right.$ $=8.8576, P<0.0001)$. A post hoc Tukey's HSD showed that significant differences were found between the test samples and control formulations, as shown in Table 5 . These slight differences may be attributed to differences in the mineral content.

Cold Flow. Cold flow is a measure of how much a caramel will flow under its own weight. It is seen as a defect in caramels when a caramel is desired to maintain its shape during production (e.g., chocolate-covered caramels). Caramels with whey protein have been well documented to show increased cold flow because of the increased flexibility of the proteins (Heathcock, 1985).

The control caramels exhibited significantly less cold flow than the caramels with WPPC and DLP. A oneway ANOVA indicated statistically significant differences of cold flow values $\left(F_{47,7}=208.7350, P<0.0001\right)$. A post hoc Tukey's HSD showed that significant differences occurred between the test samples and control formulations as seen in Table 5. Casein, present in the control formulas, is thought to aggregate around the fat globules and to provide structure to withstand the force of gravity. Whey proteins from the WPPC form fewer aggregates around the fat globules and as a re-

Table 5. Luminosity $\left(\mathrm{L}^{*}\right)$, water activity $\left(\mathrm{a}_{\mathrm{W}}\right)$, cold flow, and texture values of caramels made with whey protein phospholipid concentrate $(\mathrm{WPPC})$ and delactosed permeate-whey protein phospholipid concentrate (DLP:WPPC) blends ( $=6$; means $\pm \mathrm{SD})$

\begin{tabular}{|c|c|c|c|c|c|}
\hline Formula $^{1}$ & $\mathrm{~L}^{*}$ & $a_{W}$ & Cold flow $(\%)$ & Hardness (g) & Stickiness (g) \\
\hline$\overline{+\mathrm{C}}$ & $52.7 \pm 0.9^{\mathrm{d}}$ & $0.505 \pm 0.010^{\mathrm{a}}$ & $4.4 \pm 2.5^{\mathrm{e}}$ & $1,764.0 \pm 302.4^{\mathrm{a}}$ & $949.7 \pm 168.5^{\mathrm{c}}$ \\
\hline$-\mathrm{C}$ & $51.7 \pm 1.4^{\mathrm{d}}$ & $0.502 \pm 0.009^{\mathrm{ab}}$ & $4.2 \pm 3.4^{\mathrm{e}}$ & $2,040.2 \pm 381.4^{\mathrm{a}}$ & $990.2 \pm 60.4^{\mathrm{c}}$ \\
\hline $\mathrm{A}$ & $55.7 \pm 0.7^{\mathrm{c}}$ & $0.494 \pm 0.007^{\mathrm{abc}}$ & $53.4 \pm 4.1^{\mathrm{d}}$ & $1,339.5 \pm 90.2^{\mathrm{b}}$ & $594.8 \pm 83.0^{\mathrm{a}}$ \\
\hline $30: 70 \mathrm{~A}$ & $58.6 \pm 1.2^{\mathrm{ab}}$ & $0.495 \pm 0.007^{\mathrm{ab}}$ & $69.1 \pm 8.1^{\mathrm{c}}$ & $1,038.1 \pm 137.1^{\mathrm{bcd}}$ & $679.4 \pm 44.6^{\mathrm{ab}}$ \\
\hline B & $55.4 \pm 1.3^{\mathrm{c}}$ & $0.491 \pm 0.006^{\mathrm{bcd}}$ & $114.7 \pm 7.09^{\mathrm{b}}$ & $915.0 \pm 174.7^{\mathrm{d}}$ & $700.1 \pm 126.5^{\mathrm{ab}}$ \\
\hline $30: 70 \mathrm{~B}$ & $59.9 \pm 1.2^{\mathrm{ab}}$ & $0.487 \pm 0.005^{\mathrm{abcd}}$ & $130.7 \pm 8.9^{\mathrm{a}}$ & $999.3 \pm 208.8^{\mathrm{cd}}$ & $629.8 \pm 110.2^{\mathrm{ab}}$ \\
\hline $\mathrm{C}$ & $57.5 \pm 0.4^{\mathrm{b}}$ & $0.481 \pm 0.005^{\mathrm{cd}}$ & $54.9 \pm 10.2^{\mathrm{d}}$ & $1,222.4 \pm 263.3^{\mathrm{bcd}}$ & $599.5 \pm 37.8^{\mathrm{a}}$ \\
\hline $30: 70 \mathrm{C}$ & $60.7 \pm 1.0^{\mathrm{a}}$ & $0.480 \pm 0.007^{\mathrm{d}}$ & $56.9 \pm 10.6^{\mathrm{cd}}$ & $1,286.5 \pm 303.4^{\mathrm{bc}}$ & $739.0 \pm 46.8^{\mathrm{b}}$ \\
\hline
\end{tabular}

${ }^{\mathrm{a}-\mathrm{e}}$ Means within a column with different superscripts differ $(P<0.05)$.

${ }^{1}$ Formulas: $+\mathrm{C}=$ positive control; $-\mathrm{C}=$ negative control; $\mathrm{A}=\mathrm{WPPC} \mathrm{A} ; 30: 70 \mathrm{~A}=30 \% \mathrm{DLP}$ and $70 \% \mathrm{WPPC} \mathrm{A} ; \mathrm{B}=\mathrm{WPPC} \mathrm{B} ; 30: 70 \mathrm{~B}=$ $30 \%$ DLP and 70\% WPPC B; C =WPPC C; 30:70 C = 30\% DLP and 70\% WPPC C. 
sult produce softer, more flowable caramels (Atapattu, 1998). All caramel samples were formulated with the same protein content, but the type of protein had a significant effect on the cold flow. The caramels made without any casein exhibited significantly higher cold flows, and WPPC A and WPPC C with and without DLP exhibited more cold flow than the controls but less cold flow than the caramels made with WPPC B. Whey protein phospholipid concentrate $\mathrm{B}$ displayed poor foamability (unpublished data), indicating that the complexes could not form a viscoelastic layer between phases. The phospholipids block the proteins from forming protein-protein interactions and creating a stable layer around the fat globules in the caramel, allowing increased flow in the WPPC B caramels. The addition of DLP to WPPC also decreased the ability to form a gel network (unpublished data). Additionally, an increase of broken milk fat globule membrane (present at high concentrations in WPPC) has been shown to decrease the viscosity of the caramels compared with caramels made with less broken milk fat globule membrane, which in turn could increase cold flow (Heathcock, 1985).

Texture. Hardness and stickiness are textural qualities measured as the peak positive and peak negative forces experienced by the texture analysis probe during penetration of the caramel. They are affected by both the viscosity of the caramel and the surface chemistry (Foegeding and Steiner, 2002).

The results of the penetration test are shown in Table 5. A one-way ANOVA comparing the means of hardness indicated that significant differences existed $\left(F_{78,7}=20.5840, P<0.0001\right)$. A post hoc Tukey's HSD showed the test caramels with WPPC were significantly less hard than the controls. These results follow the literature data, showing that caramels made with whey are softer than caramels made with casein because of the increased flexibility of the whey protein aggregates (Atapattu, 1998). No significant difference in hardness was found with the addition of DLP. Samples with WPPC B were softer than samples with WPPC A. This finding could be due to the decreased strength of the protein aggregates as shown by the gel functionality (unpublished data). A one-way ANOVA comparing the means of stickiness indicated that significant differences existed $\left(F_{80,7}=25.4405, P<0.0001\right)$. A post hoc Tukey's HSD showed the test caramels were significantly less sticky than the control samples. This result again shows that the caramels with whey are less viscous than caramels made with primarily casein. The more flexible whey proteins will adhere less to the probe as it is raised and will not maintain contact as long as the stiffer casein proteins. Similar to the hardness, the stickiness can be related to the texture of the whey protein gels (unpublished data). The weak WPPC gels adhered less to the rheometer as they were removed, indicating that foods made with the WPPC would have decreased stickiness.

\section{Ice Cream}

Mix Viscosity. Ice cream mix is known to be a non-Newtonian, shear thinning fluid. The viscosity is due to both the composition and the processing of the mix. An increase in stabilizer, fat, protein, or total solids will increase the viscosity. Additionally, processing conditions such as increased pasteurization temperature or homogenization pressure will also increase the mix viscosity (Goff and Hartel, 2013). The flow index $(n)$ provides information about how a non-Newtonian fluid will behave. A value below 1 indicates a shear thinning fluid. A one-way ANOVA $\left(F_{23,7}=5.1830, P=\right.$ $0.0020)$ indicated significant differences among the flow indexes. A post hoc Tukey's HSD showed differences between the controls and tests, as seen in Table 6. All of the values show that the mixes were shear thinning. Although statistically significant, the differences were less than \pm 0.01 .

A one-way ANOVA $\left(F_{23,7}=143.1285, P<0.0001\right)$ indicated significant differences among the viscosities. A post hoc Tukey's HSD showed differences between the controls and tests. However, the viscosities ranged from 0.2 to $0.35 \mathrm{~Pa} \cdot \mathrm{s}^{-1}$. Similarly, a one-way ANOVA of the yield stress values $\left(F_{23,7}=141.0670, P<0.0001\right)$ indicated significant differences. A post hoc Tukey's HSD showed differences between the controls and test ice cream mixes, but the ranges in yield stress ranged from 0.14 to $0.37 \mathrm{~Pa}$. These values were statistically different but the differences were not large enough to influence the functionality of the mix. Small differences in viscosity and yield stress have not been shown to alter ice cream properties (Goff and Hartel, 2013).

Overrun. The overrun is a volumetric calculation of the air added to the ice cream mix during the freezing process. The ability of the mix to foam influences the overrun. An increase in emulsifiers will increase the overrun because of the functionality at the air cell interface (Goff and Hartel, 2013). A one-way ANOVA $\left(F_{47,7}\right.$ $=57.9374, P<0.0001)$ indicated significant differences among the overruns. A post hoc Tukey's HSD showed differences between the means as shown in Table 7. The positive control, with the added emulsifiers, exhibited a much higher overrun than both the test ice creams and the negative control. In general, each of the WPPCs at both levels caused a decrease in overrun. This may be attributed to 2 factors: the low amount of partially coalesced fat globules, which were not able to prevent air loss, and the poor foaming abilities of WPPC. Whey 
Table 6. Flow index, viscosity, and yield stress of ice creams mixes made with whey protein phospholipid concentrate (WPPC; $\mathrm{n}=3$; means $\pm \mathrm{SD}$ )

\begin{tabular}{lccc}
\hline Formula $^{1}$ & Flow index & $\begin{array}{c}\text { Consistency } \\
\text { coefficient }\left(\mathrm{Pa} \cdot \mathrm{s}^{-1}\right)\end{array}$ & Yield stress (Pa) \\
\hline$+\mathrm{C}$ & $0.747 \pm 0.005^{\mathrm{c}}$ & $0.289 \pm 0.012^{\mathrm{c}}$ & $0.361 \pm 0.004^{\mathrm{a}}$ \\
$-\mathrm{C}$ & $0.766 \pm 0.004^{\mathrm{a}}$ & $0.244 \pm 0.010^{\mathrm{d}}$ & $0.272 \pm 0.009^{\mathrm{bc}}$ \\
$\mathrm{A} 1$ & $0.745 \pm 0.004^{\mathrm{c}}$ & $0.299 \pm 0.002^{\mathrm{bc}}$ & $0.213 \pm 0.007^{\mathrm{e}}$ \\
$\mathrm{A} 2$ & $0.752 \pm 0.008^{\mathrm{abc}}$ & $0.379 \pm 0.010^{\mathrm{a}}$ & $0.363 \pm 0.007^{\mathrm{a}}$ \\
$\mathrm{B} 1$ & $0.759 \pm 0.001^{\mathrm{abc}}$ & $0.246 \pm 0.003^{\mathrm{d}}$ & $0.251 \pm 0.003^{\mathrm{cd}}$ \\
$\mathrm{B} 2$ & $0.747 \pm 0.005^{\mathrm{bc}}$ & $0.320 \pm 0.013^{\mathrm{b}}$ & $0.236 \pm 0.012^{\mathrm{de}}$ \\
$\mathrm{C} 1$ & $0.763 \pm 0.003^{\mathrm{ab}}$ & $0.186 \pm 0.002^{\mathrm{e}}$ & $0.149 \pm 0.003^{\mathrm{f}}$ \\
$\mathrm{C} 2$ & $0.749 \pm 0.015^{\mathrm{abc}}$ & $0.311 \pm 0.006^{\mathrm{b}}$ & $0.278 \pm 0.023^{\mathrm{b}}$ \\
\hline
\end{tabular}

${ }^{a-f}$ Means within a column with different superscripts differ $(P<0.05)$.

${ }^{1}$ Formulas: $+\mathrm{C}=$ positive control; $-\mathrm{C}=$ negative control; $\mathrm{A} 1=\mathrm{WPPC} \mathrm{A}$ at $1 \%$ addition; $\mathrm{A} 2=\mathrm{WPPC} \mathrm{A}$ at $2 \%$ addition; $\mathrm{B} 1=\mathrm{WPPC} \mathrm{B}$ at $1 \%$ addition; $\mathrm{B} 2=\mathrm{WPPC} \mathrm{B}$ at $2 \%$ addition; $\mathrm{C} 1=\mathrm{WPPC} \mathrm{C}$ at $1 \%$ addition; $\mathrm{C} 2=\mathrm{WPPC} \mathrm{C}$ at $2 \%$ addition.

protein phospholipid concentrate can act as antifoaming agents to reduce the overrun of the ice cream due to the residual lipids attached to the whey proteins (Daw and Hartel, 2015). However, overrun did not correlate to the foamability of the WPPC. Whey protein phospholipid concentrate $\mathrm{B}$ exhibited significantly lower foam height than WPPC C and A. In our previous study, no WPPC were able to hold air long enough to measure overrun and all completely collapsed in less than 1 min (unpublished data).

Ice Crystal Size. The typical range of ice crystals in ice cream is between 35 and $45 \mu \mathrm{m}$. Ice crystal size is influenced by factors such as freezing time and the amount of available water (Goff and Hartel, 2013). A one-way ANOVA $\left(F_{47,7}=20.3277, P<0.0001\right)$ indicated significant differences in ice crystal sizes among the samples. A post hoc Tukey's HSD showed differences between the means as shown in Table 7. However, differences in ice crystal size were generally small, with the mean ice crystal size only differing by less than 10 $\mu \mathrm{m}$. In addition, no clear trend appeared across WPPC type or level. All the ice crystal means were lower than the typical range found in ice cream. This result can be attributed to the fast freezing time in the batch freezer-less than 12 min.

Air Cell Size. Ice cream typically has a mean air cell size in the range of 19.9 to $38.2 \mu \mathrm{m}$ (Goff and Hartel, 2013). The mean air cell sizes of the ice creams in this study, reported in Table 7, are within the expected range in ice cream. A one-way ANOVA $\left(F_{47,7}=1.4926\right.$, $P>0.1978)$ indicated no significant differences in mean air cell size between the controls and the test formulations. The small differences in foaming properties of the different WPPC were not reflected here in average air cell sizes. Other factors that can influence air cell size include processing time, emulsifier type and level, and shear stress in the freezer. Given that freezing point temperature (shear stress due to ice formation) and processing time were the same, any differences in emulsification were small enough that air cell size was not affected.

Partial Coalescence. The amount of destabilized fat was determined from the particle size distributions, analyzed by the Malvern Mastersizer 2000. Ice cream

Table 7. Overrun, ice crystal size, air cell size, amount of partially coalesced fat, and melt rate values of ice creams made with whey protein phospholipid concentrate (WPPC; $\mathrm{n}=6$; means $\pm \mathrm{SD}$ )

\begin{tabular}{|c|c|c|c|c|c|}
\hline Formula $^{1}$ & Overrun (\%) & $\begin{array}{c}\text { Mean ice } \\
\text { crystal size }(\mu \mathrm{m})\end{array}$ & $\begin{array}{c}\text { Mean air } \\
\text { cell size }(\mu \mathrm{m})\end{array}$ & $\begin{array}{c}\text { Partially } \\
\text { coalesced fat }(\%)\end{array}$ & $\begin{array}{l}\text { Melt rate } \\
(\mathrm{g} / \mathrm{min})\end{array}$ \\
\hline$+\mathrm{C}$ & $81.2 \pm 1.7^{\mathrm{a}}$ & $22.7 \pm 1.8^{\mathrm{cd}}$ & $36.3 \pm 3.4^{\mathrm{a}}$ & $52.9 \pm 1.1^{\mathrm{a}}$ & $0.16 \pm 0.02^{\mathrm{d}}$ \\
\hline$-\mathrm{C}$ & $70.8 \pm 2.6^{\mathrm{b}}$ & $29.6 \pm 1.8^{\mathrm{ab}}$ & $34.2 \pm 2.8^{\mathrm{a}}$ & $7.5 \pm 0.2^{\mathrm{d}}$ & $1.06 \pm 0.11^{\mathrm{ab}}$ \\
\hline $\mathrm{A} 2$ & $64.3 \pm 1.6^{\mathrm{c}}$ & $26.1 \pm 3.0^{\mathrm{bc}}$ & $33.1 \pm 4.1^{\mathrm{a}}$ & $10.2 \pm 0.7^{\mathrm{c}}$ & $0.54 \pm 0.15^{\mathrm{c}}$ \\
\hline $\mathrm{B} 1$ & $68.5 \pm 4.1^{\mathrm{bc}}$ & $22.7 \pm 1.3^{\mathrm{cd}}$ & $30.2 \pm 1.3^{\mathrm{a}}$ & $6.8 \pm 0.6^{\mathrm{d}}$ & $1.04 \pm 0.09^{\mathrm{ab}}$ \\
\hline B2 & $52.0 \pm 3.7^{\mathrm{d}}$ & $22.6 \pm 1.3^{\mathrm{d}}$ & $30.8 \pm 3.1^{\mathrm{a}}$ & $12.2 \pm 0.8^{\mathrm{b}}$ & $0.98 \pm 0.07^{\mathrm{b}}$ \\
\hline
\end{tabular}

${ }^{\mathrm{a}-\mathrm{d}}$ Means within a column with different superscripts differ $(P<0.05)$.

${ }^{1}$ Formulas: $+\mathrm{C}=$ positive control; $-\mathrm{C}=$ negative control; $\mathrm{A} 1=\mathrm{WPPC} \mathrm{A}$ at $1 \%$ addition; $\mathrm{A} 2=\mathrm{WPPC} \mathrm{A}$ at $2 \%$ addition; $\mathrm{B} 1=\mathrm{WPPC} \mathrm{B}$ at $1 \%$ addition; $\mathrm{B} 2=\mathrm{WPPC} \mathrm{B}$ at $2 \%$ addition; $\mathrm{C} 1=\mathrm{WPPC} \mathrm{C}$ at $1 \%$ addition; $\mathrm{C} 2=\mathrm{WPPC} \mathrm{C}$ at $2 \%$ addition. 
mix shows 2 peaks, the casein micelles and the initial fat emulsion droplets. Three peaks are found in ice cream, with the third peak representing the partially coalesced fat in the sample, usually starting around $10 \mu \mathrm{m}$. The area under the third peak of the ice cream divided by the second peak of the ice cream mix is reported as the percent volume of the partially coalesced fat.

A one-way ANOVA $\left(F_{47,7}=2773.431, P<0.0001\right)$ indicated significant differences between the amount of partially coalesced fat in the different samples. A post hoc Tukey's HSD showed differences among the means, as seen in Table 7 . The positive control, with the emulsifiers, had significantly higher partial coalescence than the negative control and test ice creams made with WPPC. Emulsifiers promote partial coalescence by replacing the protein at the fat interface during aging and by reducing the surface tension. During freezing, the destabilized fat globules can collide and partially coalesce (Goff and Jordan, 1989). With no emulsifiers, the proteins coat the fat globules and form a protective film that prevents the majority of partial coalescence. Samples A 1\%, A 2\%, and B $2 \%$ showed significantly more partially coalesced fat than the negative control because the whey protein and phospholipid complex created a less stable film around the fat globules, which could be easily disrupted during the freezing process. These WPPC had a higher protein content than WPPC C (Table 1). Whey protein phospholipid concentrate A exhibited functionality that indicated it had a high level of native protein. The native protein would be able to function less at the fat-water interface to stabilize the fat globules. All other test formulas were not significantly different from the negative control with no emulsifiers, showing that these WPPCs did not increase partial coalescence.

Previous research also showed that addition of WPPC reduced the amount of partially coalesced fat. This result was attributed to an increased stability of the fat globules surrounded by the WPPC. However, the previous research only used WPPC D, which has the highest amount of fat and lower amounts of protein than WPPC A and B. This situation suggests that the fat in the WPPC destabilizes the emulsion, while the protein provides stabilization (Bund and Hartel, 2013; Daw and Hartel, 2015).

Melt Rate. The melt rate of ice cream is characterized by the slope of the linear region of drip-though weight $(\mathrm{g} / \mathrm{min})$ at ambient temperature over $2 \mathrm{~h}$. It is affected by ice crystal size, air cell size, air content, and fat globule size (Goff and Hartel, 2013). A one-way $\operatorname{ANOVA}\left(F_{47,7}=57.9374, P<0.0001\right)$ indicated significant differences among the test and control samples. A post hoc Tukey's HSD showed differences among the means as shown in Table 7 . The positive control, with emulsifiers, melted the slowest and had a large amount of foam remaining on the screen after $2 \mathrm{~h}$. This stability is due to the increased structure caused by the greater amount of partially coalesced fat. Sample A 2\% was the only ice cream that had a significantly slower melt rate than the negative control. However, it still completely melted though the screen similar to all of the other test ice creams and the negative control made without emulsifiers. Total melt was also found with ice creams made with WPPC in Daw and Hartel (2015).

\section{Cake}

Yield. The yield of the cake is a measure of how much water is lost during the baking process. It was measured by taking the final bake weight divided by the weight of the batter. A one-way ANOVA $\left(F_{13,6}=\right.$ $1.4251, P=0.3247)$ showed no significant differences among the yields of the cakes. A post hoc Tukey's HSD showed no differences between the means, as seen in Table 8. Previous research with DLP:WPPC blends showed a small decrease in yield with an increase in DLP over 30\% (unpublished data). When just WPPC was added, the yield did not significantly change, which can be attributed to the water holding capacity of the WPPC maintaining the same moisture as the whole eggs. Previous research has shown that eggs and whey proteins can hold similar amounts of water (Ratnayake et al., 2012).

Volume. The volume of the cake was measured using a rapeseed displacement method. A one-way ANOVA $\left(F_{41,6}=18.7129, P<0.0001\right)$ showed significant differences among the volumes of the cakes. A post hoc Tukey's HSD indicated differences as shown in Table 8. The cakes made with WPPC A were not significantly different from the control, which can be attributed to its higher gelling functionality than other WPPC (unpublished data). As WPPC A denatured during baking, the protein aggregates were able to form structures to trap the air during the cake rising and maintain a larger crumb structure. The cakes made with WPPC B and $\mathrm{C}$ had significantly lower volumes than the control because of the lack of gelling functionality, even when they were added at the same protein levels. These gels were not able to hold the air as the cake rose because the gel structure was weaker. The addition of DLP did not significantly affect the volume because the protein content remained the same. Previous research has shown decreased volume with DLP addition at $30 \%$ but did not test the WPPC alone to investigate if the decrease in volume was due to WPPC or DLP (unpublished data). The WPPC exhibited less foaming ability 
Table 8. Analytical results of cakes made with whey protein phospholipid concentrate (WPPC) and delactosed permeate-whey protein phospholipid concentrate (DLP:WPPC) blends $(\mathrm{n}=6$; means $\pm \mathrm{SD})$

\begin{tabular}{|c|c|c|c|c|c|}
\hline \multirow[b]{2}{*}{ Formula $^{1}$} & \multicolumn{5}{|c|}{ Analysis $^{2}$} \\
\hline & Yield (\%) & Volume (mL) & Contour $(\mathrm{cm})$ & $\mathrm{L}^{*}$ & $a_{W}$ \\
\hline $\begin{array}{l}\text { Control } \\
\text { A } \\
30: 70 \mathrm{~A} \\
\text { B } \\
30: 70 \mathrm{~B} \\
\mathrm{C} \\
30: 70 \mathrm{C}\end{array}$ & $\begin{array}{l}89.7 \pm 2.0^{\mathrm{a}} \\
88.5 \pm 1.2^{\mathrm{a}} \\
88.8 \pm 1.6^{\mathrm{a}} \\
88.4 \pm 0.6^{\mathrm{a}} \\
86.4 \pm 1.5^{\mathrm{a}} \\
88.2 \pm 0.1^{\mathrm{a}} \\
87.3 \pm 1.0^{\mathrm{a}}\end{array}$ & $\begin{array}{l}1,262 \pm 34^{\mathrm{a}} \\
1,196 \pm 18^{\mathrm{ab}} \\
1,213 \pm 61^{\mathrm{ab}} \\
1,063 \pm 61^{\mathrm{d}} \\
1,054 \pm 43^{\mathrm{d}} \\
1,146 \pm 43^{\mathrm{bc}} \\
1,125 \pm 34^{\mathrm{cd}}\end{array}$ & $\begin{array}{l}1.55 \pm 0.42^{\mathrm{a}} \\
0.40 \pm 0.07^{\mathrm{b}} \\
0.23 \pm 0.25^{\mathrm{b}} \\
0.18 \pm 0.11^{\mathrm{b}} \\
0.25 \pm 0.14^{\mathrm{b}} \\
0.13 \pm 0.11^{\mathrm{b}} \\
0.18 \pm 0.18^{\mathrm{b}}\end{array}$ & $\begin{array}{l}65.0 \pm 2.07^{\mathrm{a}} \\
65.6 \pm 2.69^{\mathrm{a}} \\
64.6 \pm 3.39^{\mathrm{a}} \\
64.7 \pm 1.12^{\mathrm{a}} \\
63.2 \pm 1.05^{\mathrm{a}} \\
65.8 \pm 1.17^{\mathrm{a}} \\
62.7 \pm 1.86^{\mathrm{a}}\end{array}$ & $\begin{array}{l}0.899 \pm 0.013^{\mathrm{a}} \\
0.901 \pm 0.009^{\mathrm{a}} \\
0.900 \pm 0.011^{\mathrm{a}} \mathrm{a} \\
0.902 \pm 0.006^{\mathrm{a}} \\
0.898 \pm 0.008^{\mathrm{a}} \\
0.905 \pm 0.004^{\mathrm{a}} \\
0.896 \pm 0.007^{\mathrm{a}}\end{array}$ \\
\hline
\end{tabular}

than the eggs, but volume can also be attributed to the proteins, gluten, found in the flour. The gluten content may override the effect of the WPPC addition.

Height. The contour of the cake is a measure of the difference between the height of the side of the cake and the height at the center of the cake when it is cut in half. A one-way ANOVA $\left(F_{27,6}=11.3099, P=0.0027\right)$ indicated differences among the control and the test cakes, as shown in Table 8. The contour of the control was significantly higher than the test cakes. This can be attributed to the lack of foaming abilities of the WPPC and DLP:WPPC blends. Eggs are much better at foaming because of the egg white proteins. WPPC is not good at foaming because of the high lipid content, which prevents the proteins from forming a layer around the air cells.

Colorimetry. The color in cake is due to the Maillard browning that occurs during the baking process. The reducing sugars react with the free amino groups to form brown pigments. The intensity of this can be measured by the luminosity of the surface of the cake. A one-way ANOVA $\left(F_{41,6}=1.8899, P=0.1103\right)$ showed no significant differences among the colors of the cake crusts. A post hoc Tukey's HSD showed no differences, as shown in Table 8. This finding can be attributed to 2 things. First, the increased lactose content in the test formulas was not high enough to cause significant changes in the concentration of Maillard browning product. Second, the variation of the color of the cake was large enough to outweigh any changes in color caused by composition. In previous research, an increase in the darkness of the cakes was only observed with DLP addition of $50 \%$ (K. J. Burrington, unpublished data).

Water Activity. A one-way ANOVA $\left(F_{41,6}=\right.$ $0.6501, P=0.6897)$ indicated no significant differences among the water activities of the cakes. A post hoc Tukey's HSD showed no differences, as shown in Table
8. The main driving factors in the water activity in cake would be the water content and the concentration of low molecular weight molecules. The amount of sugar was kept constant and not enough DLP was added to make a significant difference in the concentration of small molecular weight molecules.

Texture Profile Analysis. The texture of the cakes was measured by performing a texture profile analysis test. This test involves 2 compressions and gives insight into how a food will behave when chewed (Texture Technologies, 2012). For the cake samples, hardness, cohesiveness, and springiness were analyzed. Hardness is used to evaluate the softness and ease of the first bite. Cohesiveness quantifies the internal resistance of the cake, and springiness indicates how much the structure will recover after pressure is applied (Tan et al., 2015). All texture profile analysis data are shown in Table 9 .

Hardness was measured as the maximum force of the first compression. A one-way $\mathrm{ANOVA}\left(F_{69.6}=\right.$ 2.2067, $P=0.0543)$ showed no significant differences in hardness of the cakes. The whey proteins created an internal structure that had similar resistance to force than a structure created by whole eggs. It can also be noted that the control cake had the highest variation in hardness and the test cakes created a more consistent crumb. This finding could be attributed to the more dense structure of the test cakes, which had fewer air pockets as shown in the reduction in volume.

Cohesiveness was measured by the area of work during the second compression divided by the area of work during the first compression. A one-way ANOVA $\left(F_{69,6}\right.$ $=5.4746, P=0.0002)$ showed significant differences among the cohesiveness values of the cakes. A post hoc Tukey's HSD showed that the cake made with the 30:70 DLP:WPPC C blend had significantly lower cohesiveness than all other cakes. This blend could have had 
Table 9. Texture profile analysis results of cakes made with whey protein phospholipid concentrate (WPPC) and delactosed permeate-whey protein phospholipid concentrate (DLP:WPPC) blends $(\mathrm{n}=10$; means $\pm \mathrm{SD})$

\begin{tabular}{lccc}
\hline & \multicolumn{3}{c}{ Texture profile analysis } \\
\cline { 2 - 4 } Formula $^{1}$ & Hardness $(\mathrm{g})$ & Cohesiveness & Springiness $(\mathrm{mm})$ \\
\hline Control & $170.5 \pm 46.2^{\mathrm{a}}$ & $1.1 \pm 0.1^{\mathrm{a}}$ & $1.0 \pm 0.02^{\mathrm{a}}$ \\
$\mathrm{A}$ & $130.9 \pm 20.0^{\mathrm{a}}$ & $1.1 \pm 0.1^{\mathrm{a}}$ & $1.0 \pm 0.01^{\mathrm{a}}$ \\
$30: 70 \mathrm{~A}$ & $155.9 \pm 40.8^{\mathrm{a}}$ & $1.1 \pm 0.1^{\mathrm{a}}$ & $1.0 \pm 0.01^{\mathrm{a}}$ \\
$\mathrm{B}$ & $151.1 \pm 18.5^{\mathrm{a}}$ & $1.1 \pm 0.2^{\mathrm{a}}$ & $1.0 \pm 01^{\mathrm{a}}$ \\
$30: 70 \mathrm{~B}$ & $177.5 \pm 22.8^{\mathrm{a}}$ & $1.2 \pm 0.1^{\mathrm{a}}$ & $1.0 \pm 0.01^{\mathrm{a}}$ \\
$\mathrm{C}$ & $162.0 \pm 41.0^{\mathrm{a}}$ & $1.2 \pm 0.1^{\mathrm{a}}$ & $1.0 \pm 0.01^{\mathrm{a}}$ \\
30:70 C & $170.7 \pm 26.1^{\mathrm{a}}$ & $0.9 \pm 0.1^{\mathrm{b}}$ & \\
${ }^{\mathrm{a}, \mathrm{b}}$ Means within a column with different superscripts differ $(P<0.05)$. & \\
${ }^{1}$ Formulas: A $=$ WPPC A; $30: 70 \mathrm{~A}=30 \%$ DLP and $70 \%$ WPPC A; B $=$ WPPC B; $30: 70 \mathrm{~B}=30 \%$ DLP and \\
70\% WPPC B; C = WPPC C; 30:70 C = 30\% DLP and 70\% WPPC C.
\end{tabular}

less protein-protein interactions, which would have reduced the strength of the internal structure, making it less resistant to external forces. Additionally, the 30:70 DLP:WPPC C was not able to form a strong gel because of the DLP preventing the proteins from forming a strong network. It should be noted that the difference, though significant, was slight.

Springiness was calculated as the distance of the detected height during the second compression divided by the original compression distance. A one-way ANOVA $\left(F_{69,6}=1.5362, P=0.1817\right)$ showed no significant differences among the springiness values of the cakes. The cakes recovered to a similar height after compression, showing that the whey proteins provided a similar structure to the egg proteins.

\section{CONCLUSIONS}

In the food applications, WPPC and 30:70 DLP:WPPC blends were added to replace products that are more expensive. In caramel, WPPC and 30:70 DLP:WPPC blends replaced sweetened condensed skim milk (protein replacement) and lecithin. The test caramels showed slightly decreased browning and similar water activities. A large increase occurred in cold flow, and hardness and stickiness both decreased. Results were similar to previous studies that indicated significant differences in caramels made with whey protein instead of casein protein. Overall, WPPC and DLP:WPPC blends cannot be used to fully replace sweetened condensed skim milk and lecithin in chewy caramels. However, they might be used in caramel sauces, in which texture and flow are less of a concern. In ice cream, WPPC was added at $1 \%$ and $2 \%$ of the formulation to replace synthetic emulsifiers and compared to a control ice cream made with polysorbate 80 and mono- and diglycerides and a control ice cream with no emulsifiers added. The test ice cream mixes made with WPPC showed slight differences in the viscosity, flow index, and yield stress. The WPPC ice creams had a lower overrun than both the control ice creams. The ice crystal and air cell sizes were not greatly different and could be attributed to the variability of making ice creams in a batch freezer. The amount of partially coalesced fat in the test ice creams was significantly lower than the control ice cream with emulsifiers. Most test ice creams were not significantly different from the control ice cream with no emulsifiers, except ice creams made with $1 \%$ and $2 \%$ WPPC A and $2 \%$ WPPC B. All melt rates of the test ice cream were faster than the control ice cream with emulsifiers. Overall, synthetic emulsifiers cannot be fully replaced in ice cream to produce identical attributes in ice cream, but WPPC A and B did show a small increase in partially coalesced fat at a level similar to some industry ice creams. If synthetic emulsifiers are replaced by WPPC, a cleaner ingredients label could be produced. Cakes were studied to examine the effect of replacing whole eggs with WPPC or blends of 30:70 DLP:WPPC. The yields of the cake with eggs and the test cakes did not differ. The volumes of the cakes made with WPPC B and C and their DLP blends were lower than the cake made with eggs. The contour of all the test cakes was lower than the control cake and produced a flatter cake. Water activity and texture were not altered with the replacement. Overall, eggs could be fully replaced by WPPC and DLP:WPPC blends to produce an acceptable cake. Based on these results, WPPC has significant potential for food applications, potentially in concert with DLP. Future work on other applications is warranted.

\section{ACKNOWLEDGMENTS}

We would like to acknowledge the National Dairy Council (Rosemont, IL) for funding this work. 


\section{REFERENCES}

AACC International. 2009. Method 10-05.01. Measurement of volume by rapeseed displacement. In Approved Methods of Analysis. 11th ed. AACC International, St. Paul, MN.

American Dairy Products Institute. 2015. Whey protein phospholipid concentrate (WPPC) standard. Accessed Nov. 4, 2015. http://www.adpi.org/Portals/0/Standards/ WheyProteinPhospholipidConcentrate_book.pdf.

Atapattu, C. 1998. Milk protein functionality in caramel processing. $\mathrm{PhD}$ Thesis. Food Science Dept., Univ. of Guelph, Ottawa, ON.

Bruttel, P., and R. Schlink. 2003. Determination by Karl Fischer Titration. Metrom Herisau, Switzerland.

Bund, R. K., and R. W. Hartel. 2013. Blends of delactosed permeate and pro-cream in ice cream: Effects on physical, textural and sensory attributes. Int. Dairy J. 31:132-138.

Burrington, K. J. 2011. Applications monograph: Permeate for sodium reduction. Accessed May 4, 2015. http://www.usdairy.com/ / media/usd/public/coproducts_milk_report.pdf.

Chang, Y., and R. W. Hartel. 2002. Measurement of air cell distributions in dairy foams. Int. Dairy J. 12:463-472.

Daw, E., and R. Hartel. 2015. Fat destabilization and melt-down of ice creams with increased protein content. Int. Dairy J. 43:33-41.

Donhowe, D., R. W. Hartel, and R. C. Bradley Jr.. 1991. Ice crystallization processes during manufacture and storage of ice cream. J. Dairy Sci. 74:3334-3344.

Foegeding, E. A., and A. Steiner. 2002. Factors regulating caramel stickiness and texture. The Manufacturing Confectioner 82:81-88.

Goff, H., and W. Jordan. 1989. Action of emulsifiers in promoting fat destabilization during the manufacture of ice cream. J. Dairy Sci. $72: 18-29$.

Goff, H. D., and R. W. Hartel. 2013. Ice Cream. 7th ed. Springer, New York, NY

Heathcock, J. F. 1985. Characterisation of milk proteins in confectionery products. Food Structure. 4:17-27.
Hofberger, R. 2009. Caramel 101. The Manufacturing Confectioner. 89:31-37.

Jackson, B. 2000. Fundamentals of Sugar Confectionery. Pennsylvania Manufacturing Confectioner's Assoc., Hershey, PA.

Liang, B., R. K. Bund, and R. W. Hartel. 2009. Effect of composition on moisture sorption of delactosed permeate. Int. Dairy J. 19:630-636.

McMaster, T. J., A. C. Smith, and P. Richmond. 1987. Physical and rheological characterization of a confectionery product. J. Texture Stud. 18:319-334.

Miller, E. C. 2012. Effects of formulation changes on crystal content and texture in caramel. MS Thesis. Food Science Dept., Univ. of Wisconsin, Madison.

Muse, M. R., and R. W. Hartel. 2004. Ice cream structural elements that affect melting rate and hardness. J. Dairy Sci. 87:1-10.

Nielsen, S. 2010. Food Analysis. Springer, New York, NY.

Ratnayake, W. S., B. Geera, and D. A. Rybak. 2012. Effects of egg and egg replacers on yellow cake product quality. J. Food Process. Preserv. 36:21-29.

Tan, M. C., N. L. Chin, and Y. A. Yusof. 2015. Improvement of eggless cake structure using ultrasonically treated whey protein. Food Bioprocess Technol. 8:605-614.

Texture Technologies. 2012. An overview of texture profile analysis (TPA). Accessed Mar. 27, 2015. http://texturetechnologies.com/ texture-profile-analysis/texture-profile-analysis.php.

US Food and Drug Administration (FDA). 2015. Ice cream and frozen custard. 21CFR135.110. Accessed Jun. 14, 2016. http:// www.accessdata.fda.gov/scripts/cdrh/cfdocs/cfcfr/cfrsearch. $\operatorname{cfm} ? \mathrm{fr}=135.110$.

Warren, M. M., and R. W. Hartel. 2015. Structural, compositional, and sensorial properties of United States commercial ice cream products. J. Food Sci. 79:E2005-E2013. 